Article

\title{
Optimization Mechanism of Additive of Composite Sodium Salts on Vanadium Oxidation of Siliceous Shale
}

\author{
Xinlong Yang ${ }^{1}$, Yali Feng ${ }^{1, *}$, Haoran $\mathrm{Li}^{2}$ and $\mathrm{Zhuwei} \mathrm{Du}^{2}$ \\ 1 School of Civil and Resource Engineering, University of Science and Technology Beijing, Beijing 100083, \\ China; yx15071@163.com \\ 2 State Key Laboratory of Biochemical Engineering, Institute of Process Engineering, \\ Chinese Academy of Sciences, Beijing 100190, China; hrli@ipe.ac.cn (H.L.); zwdu@ipe.ac.cn (Z.D.) \\ * Correspondence: ylfeng126@126.com
}

Received: 1 May 2017; Accepted: 12 June 2017; Published: 17 June 2017

\begin{abstract}
The promotion of strengthening of vanadium oxidation by compound additive of sodium salts is described from the changes of the vanadium valence state and mineral phase. The results are as follows: during the roasting process, dehydroxy mica converts to the melt, which the composite system mainly contains $\mathrm{Na}, \mathrm{K}, \mathrm{Al}, \mathrm{Si}$, and $\mathrm{O}$. Under the action of $\mathrm{NaCl}-\mathrm{Na}_{2} \mathrm{CO}_{3}$, ion exchange between sodium and potassium promotes the crystallization of albite from the melt. $\mathrm{Na}_{2} \mathrm{CO}_{3}$ enhances the reactivity of quartz. The albite reacts with activated quartz, which promotes the migration of sodium ions and the generation of vanadate. Under the action of $\mathrm{NaCl}-\mathrm{Na}_{2} \mathrm{SO}_{4}$, The crystallization of spinel in the melt is promoted and that of the albite is inhibited. Under the action of $\mathrm{Na}_{2} \mathrm{SO}_{4}-\mathrm{Na}_{2} \mathrm{CO}_{3}$, the permeability of ore is deteriorated. The ion exchange process and the vanadium oxidation is inhibited from the melt. The composite additive with three sodium salts shows a stronger promoting effect on vanadium oxidation. The contribution of $\mathrm{NaCl}$ and $\mathrm{Na}_{2} \mathrm{CO}_{3}$ to $\mathrm{V}(\mathrm{V})$ in roasted slag was the highest among three sodium salts. With a certain ratio of $\mathrm{NaCl}$ and $\mathrm{Na}_{2} \mathrm{CO}_{3}$, the low content of $\mathrm{Na}_{2} \mathrm{SO}_{4}$ did not significantly affect the $\mathrm{V}(\mathrm{V})$ content in roasted slag.
\end{abstract}

Keywords: siliceous shale; vanadium oxidation; phase change; synergistic effect

\section{Introduction}

Roasting is one of the important steps of the recycling of various metals in siliceous shale [1]. Additives contribute to the extraction of vanadium during the roasting process has been the consensus [2]. During the process of recovering vanadium from shale, sodium salt occupies a very important position in roasting additives. Since a single sodium salt only obtains a low vanadium extraction rate, researchers tend to mix two or three kinds of sodium salts as a composite additive, so as to enhance the leaching rate of vanadium [3,4]. Muscovite, the major mineral phase that vanadium exists in, will release vanadium after removing the hydroxyl in the lattice $[5,6]$. The extraction of vanadium at high temperature will be influenced by the change of the mineral phase and the valence state of vanadium under the action of composite additives. Therefore, the mechanism of the composite sodium salts on the phase of the siliceous shale has become an urgent problem that needs to be resolved currently. As an important additive, some research results of the action mechanism of $\mathrm{NaCl}$ during roasting process have been obtained. Due to the oxidizability of chlorine, $\mathrm{NaCl}$ can strongly promote the oxidation of vanadium [7]. $\mathrm{Na}_{2} \mathrm{SO}_{4}$ and $\mathrm{Na}_{2} \mathrm{CO}_{3}$ have less effect on the promotion of vanadium oxidation than $\mathrm{NaCl}$. However, they are cheaper and plenty, and cause less pollution than $\mathrm{NaCl}$. Thus, they are used to mix into $\mathrm{NaCl}$ to reduce the generation of harmful gases $[8,9]$. At present, there is insufficient understanding of the functional mechanism of composite sodium salts when they are 
mixed with ores and roasted [10], and there are only some empirical formulas for the ratio of the three sodium salts to improve the leaching rate of vanadium [11].

In this paper, the action process of the composite sodium salt of $\mathrm{NaCl}, \mathrm{Na}_{2} \mathrm{CO}_{3}$, and $\mathrm{Na}_{2} \mathrm{SO}_{4}$ in roasting is elucidated by the analyses of the mineral phase change and vanadium oxidation. The vanadium extraction mechanisms and the optimization of vanadium oxidation by the composite additive is studied for the guidance and reference of its industrial application.

\section{Materials and Methods}

\subsection{Material}

The siliceous shale used in the test was obtained from Hubei Province, China. The raw ore has been crushed and ground to powder with the particle size smaller than $0.6 \mathrm{~mm}$, preliminarily. Tables 1 and 2, respectively, show chemical multi-elemental analysis and vanadium valence composition analysis of raw ore. Chemical compositions of samples were determined by X-ray Fluorescence (XRF, AxiosMAX, PANalytical B.V., Almelo, The Netherlands). The valence state of vanadium of the sample were determined by potentiometric titration. The XRD pattern (Figure 1), which were determined by X-ray diffraction analysis (XRD, SmartLab(9), Rigaku, Tokyo, Japan), showed that the main minerals, including quartz, muscovite, illite, and kaolinite.

Table 1. Chemical multi-elemental analysis of siliceous shale (wt \%).

\begin{tabular}{|c|c|c|c|c|c|c|c|c|c|}
\hline \multirow{4}{*}{$\begin{array}{c}\text { Chemical } \\
\text { Multi-Elemental } \\
\text { Analysis }\end{array}$} & $\mathrm{Na}_{2} \mathrm{O}$ & $\mathrm{MgO}$ & $\mathrm{Al}_{2} \mathrm{O}_{3}$ & $\mathrm{SiO}_{2}$ & $\mathrm{~K}_{2} \mathrm{O}$ & $\mathrm{CaO}$ & $\mathrm{V}_{2} \mathrm{O}_{5}$ & $\mathbf{P}$ & $\mathrm{S}$ \\
\hline & 0.13 & 1.36 & 9.63 & 79.16 & 1.24 & 0.69 & 1.72 & 1.37 & 0.28 \\
\hline & As & $\mathrm{Ti}$ & $\mathrm{Cr}$ & $\mathrm{Fe}$ & $\mathrm{Zn}$ & $\mathrm{Pb}$ & & & \\
\hline & 1.32 & 0.26 & 0.25 & 2.18 & 0.06 & 0.01 & & & \\
\hline
\end{tabular}

Table 2. Valence composition of vanadium in siliceous shale (wt \%).

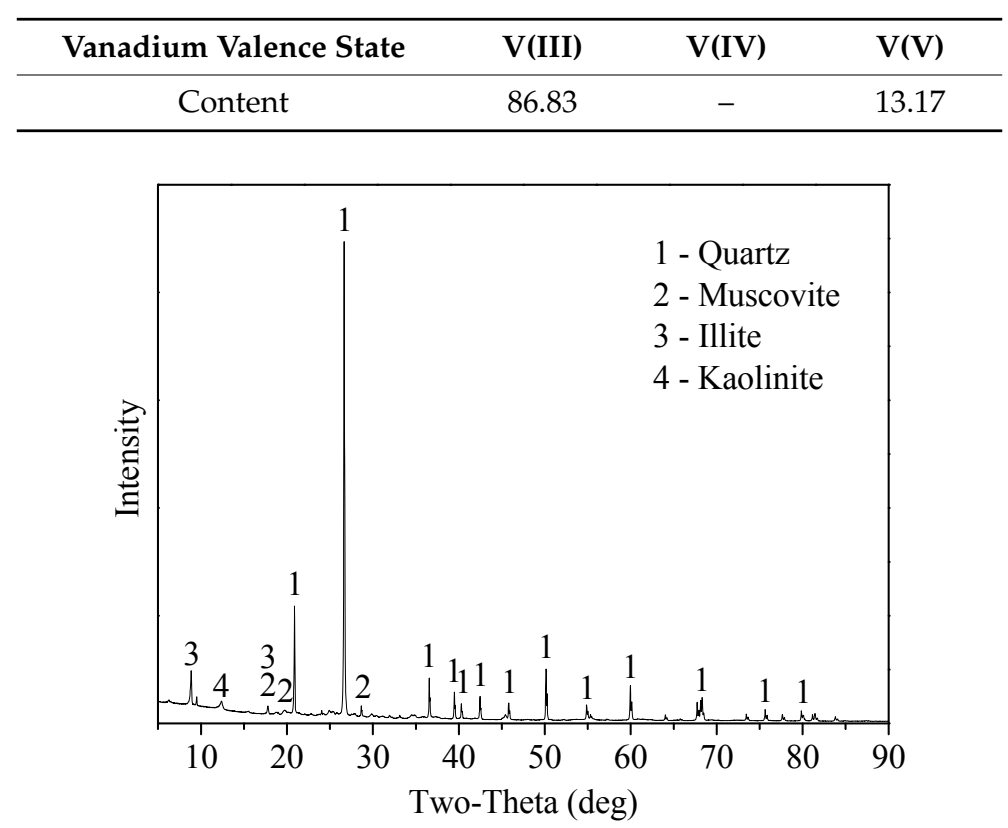

Figure 1. The XRD pattern of raw ore.

\subsection{Experimental Procedure}

The ore sample was further ground to powder with the particle size smaller than $0.074 \mathrm{~mm}$. Three groups of the same quality ores were taken as experimental samples. Different proportions of two 
combinations of the three sodium salts $\left(\mathrm{NaCl}, \mathrm{Na}_{2} \mathrm{CO}_{3}\right.$, and $\left.\mathrm{Na}_{2} \mathrm{SO}_{4}\right)$ were mixed in the samples, respectively, according to the $10 \%$ of the total amount of additives. These samples were roasted at $1073 \mathrm{~K}$ for $4 \mathrm{~h}$. The roasted slags were leached in water at $353 \mathrm{~K}$ for $2 \mathrm{~h}$, and the ratio of liquid to solid was 10:1. Then, three single salts are mixed with the same ore samples, respectively, according to the proportion of it in composite additive and roasted at the same conditions. Moreover, keeping the total amount of additives constant and different sodium salt ratio, the same quality samples which are mixed with three salts of composite additives are roasted.

The content and valence state of vanadium of roasted slag and leaching residue were determined by the titrimetric method [12]. Microscopic observation and analysis of element distribution in leaching residues were conducted by scanning electron microscopy (SEM, JSM-7001F, Japan Electron Optics Laboratory, Tokyo, Japan) equipped with energy-disperse X-ray spectrometry (EDS, INCA X-Max, Oxford Instruments, Oxford, UK).

\section{Results and Discussion}

\subsection{Influence of Composite Additive of Two Salts on the Change of Vanadium Valence}

In order to clarify the mechanism of $\mathrm{V}(\mathrm{V})$ content changes, the valence of vanadium of leaching residues and solutions were analyzed. The leaching residues of composite additive of two salts contained only V(IV). Moreover, the sum of the two-part content of vanadium was close to the total vanadium content in the raw ore. It indicated that after roasting, the structure of mica in the ore was destroyed and the V(III) was completely oxidized to V(IV). V(IV) eventually converted to soluble vanadate. During the phase change of ore in roasting, the rest of the V(IV) remained in the ore and cannot be leached. Different composite additives affected the above process and changed the vanadium extraction.

As shown in Figure 2, the composite additive of $\mathrm{NaCl}$ and $\mathrm{Na}_{2} \mathrm{CO}_{3}$ has the strongest effect on transformation of $\mathrm{V}(\mathrm{IV})$, while the composite additive of $\mathrm{Na}_{2} \mathrm{SO}_{4}$ and $\mathrm{Na}_{2} \mathrm{CO}_{3}$ has the weakest effect. For the curve of $\mathrm{NaCl}-\mathrm{Na}_{2} \mathrm{CO}_{3}$, the content of $\mathrm{V}(\mathrm{IV})$ decreased and gradually transformed with the increase of the proportion of $\mathrm{NaCl}$. When the ratio was greater than 2:3, the transformation of $\mathrm{V}(\mathrm{IV})$ gradually stopped. To the curve of $\mathrm{NaCl}-\mathrm{Na}_{2} \mathrm{SO}_{4}$, the content of $\mathrm{V}(\mathrm{IV})$ also decreased with the increase of the proportion of $\mathrm{NaCl}$. While, for the curve of $\mathrm{Na}_{2} \mathrm{SO}_{4}-\mathrm{Na}_{2} \mathrm{CO}_{3}$, the contribution of composite additive to the transformation of V(IV) was less, and the decrease of $\mathrm{V}$ (IV) content in leaching residue was smaller.

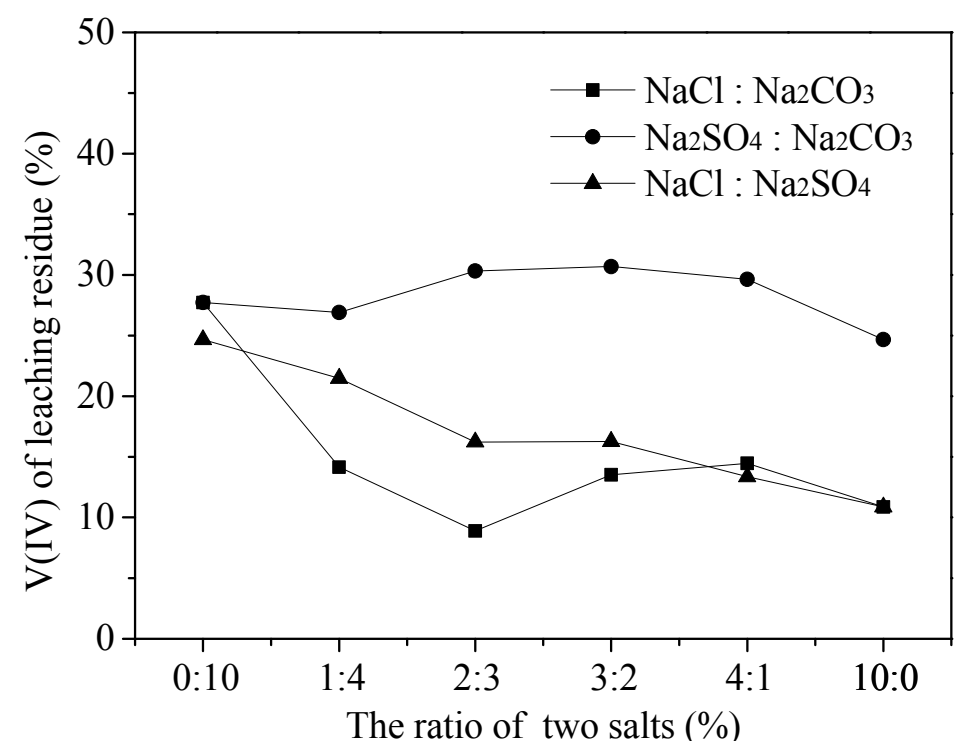

Figure 2. The V(IV) of leaching residue of composite additives of two sodium salts. 


\subsection{Synergistic Effect between Two Sodium Salts on the Vanadium Oxidation and Mineral Phase Change}

\subsubsection{Influence of Composite Additive on the V(V) Content of Roasted Slag}

Assuming that each salt in the composite additive does not act synergistically with the other salt, three of single salts are mixed with samples, respectively, according to the proportion of it in the composite additive and roasted. $\mathrm{V}(\mathrm{V})$ contents of the two corresponding roasted slags are added together. The oxidation effect of composite additives on vanadium without considering the synergistic effect between salts can be obtained. It is defined as the weighted value of $V(V)$, which can be calculated by Equation (1):

$$
\Sigma=\frac{\mathrm{Ax}+\mathrm{By}}{10} \times 100 \%
$$

where $\Sigma$ is the weighted value of $\mathrm{V}(\mathrm{V})$; $\mathrm{A}$ and $\mathrm{B}$ are the proportion of the two salts in the sample, respectively; $x$ and $y$ are the content of $V(V)$ in samples which, respectively, mixed with the single salt of the proportion of $\mathrm{A}$ and $\mathrm{B}$ and roasted.

The content of actual $V(V)$ and weighted value of $V(V)$ in roasted slags are shown in Figure 3.

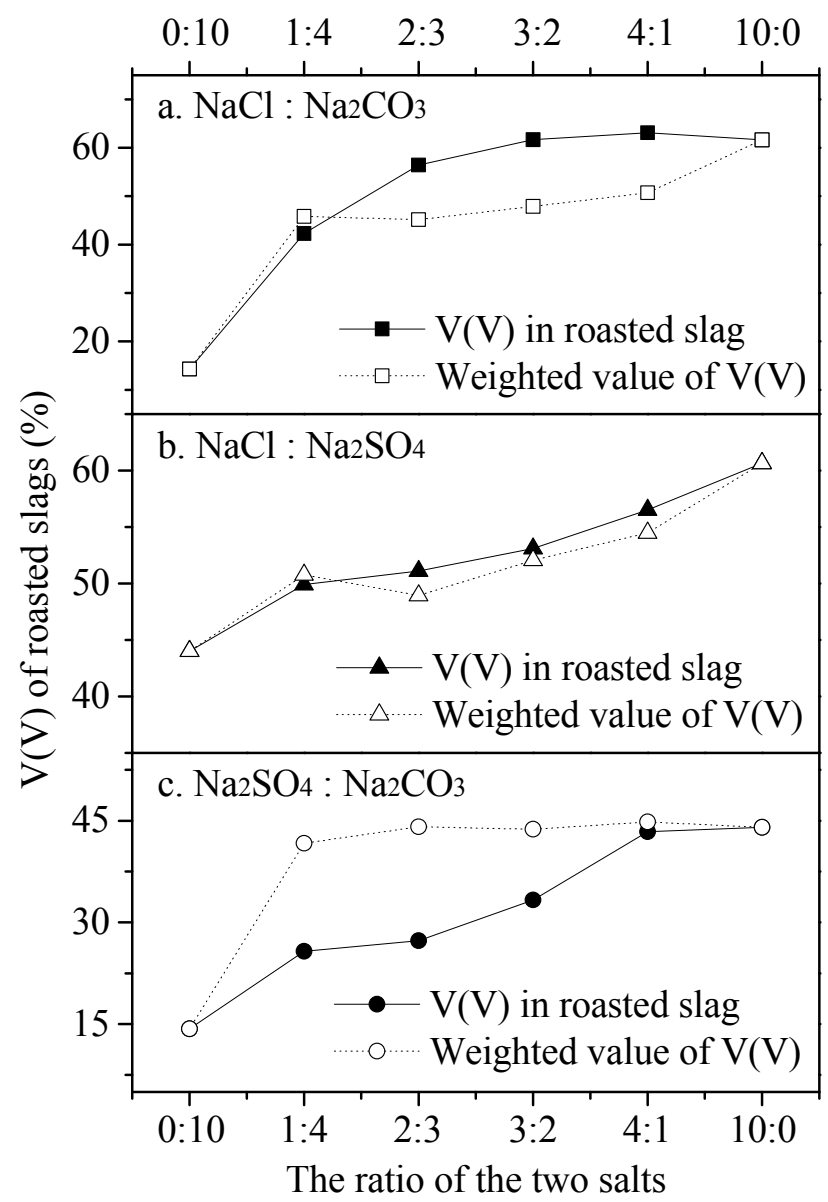

Figure 3. Influence of the ratio of two salts on $\mathrm{V}(\mathrm{V})$.

Figure 3 shows the influence of different ratios of two salts on $V(V)$ of roasted slag. In Figure 3 , the solid line represents the measured value. The dash line represents the weighted value that was calculated from Equation (1). As shown in Figure 3, the changes of the contents of $V(V)$ differ from each other. This phenomenon would be discussed in the following parts.

In Figure 3a, with the increase of the proportion of $\mathrm{NaCl}$ in the composite additive, $\mathrm{V}(\mathrm{V})$ also increased. After the ratio of the two salts is greater than $3: 2$, the $V(V)$ content is not increased obviously. 
This indicates that the mixture of a small amount of $\mathrm{Na}_{2} \mathrm{CO}_{3}$ into $\mathrm{NaCl}$ does not affect the $\mathrm{V}(\mathrm{V})$ content in the roasted slag. Meanwhile, in the range of two salt ratios from 1:4 to 10:0, the weighted value of $\mathrm{V}(\mathrm{V})$ is lower than the $\mathrm{V}(\mathrm{V})$ that actually contained in roasted slag. This shows that the composite additive promotes the oxidation process of vanadium and increases the $V(V)$ content in the fore mentioned ratio range.

In Figure $3 b, \mathrm{~V}(\mathrm{~V})$ of roasted slag increases uniformly with the increase of the proportion of $\mathrm{NaCl}$ in the composite additive. Unlike the rapid decrease of $\mathrm{V}(\mathrm{V})$ in Figure $3 \mathrm{a}, \mathrm{V}(\mathrm{V})$ decreases less when $\mathrm{Na}_{2} \mathrm{SO}_{4}$ increases in Figure 3b. At each ratio, the $\mathrm{V}(\mathrm{V})$ of roasted slag and the weighted value of $\mathrm{V}(\mathrm{V})$ are always close. This indicates that the two salts reacts independently with ore; there have no obvious synergies between each other.

In Figure 3c, $\mathrm{V}(\mathrm{V})$ increases with the increase of the proportion of $\mathrm{Na}_{2} \mathrm{SO}_{4}$. It is clear that the ratio of the two salts is greater than 4:1, while the $\mathrm{V}(\mathrm{V})$ content does not increase obviously. The composite additives of these two salts have less promotion than the other two on the oxidation of vanadium. In addition, in the range of two salt ratios from 0:10 to 4:1, the $\mathrm{V}(\mathrm{V})$ actually contained in roasted slag was lower than the weighted value of $\mathrm{V}(\mathrm{V})$. This figure indicates that the composite additive hindered the oxidation process of vanadium and reduces the $\mathrm{V}(\mathrm{V})$ content in the above ratio range.

\subsubsection{Influence of Composite Additive on the Mineral Phase Change in Roasting}

According to the current research achievements, vanadium of siliceous shale is mainly exist in alumina octahedral of mica group minerals in the form of isomorphism [13]. After roasting, muscovite in raw ore is damaged and converts to other phases on the effect of additives. Heteromorphism is found in the phase of feldspar of roasted slag. When alumina octahedral in the crystal lattice of muscovite is damaged, the ions of alumina, magnesium, vanadium, and other metals were released. With a high temperature roasting, eutectic composite was generated in ore and change the crystal structure [14]. The behavior hindered the oxidation of vanadium and led to the low leaching rate of vanadium.

For the further study of the effect of composite additives on the vanadium oxidation, the leaching residue of different composite additives were analyzed on mineral phase. The results are shown from Figures 4-6.

Figure 4 shows the leaching residue after adding the composite additive of $\mathrm{NaCl}-\mathrm{Na}_{2} \mathrm{CO}_{3}$. It can be seen that melt (1\#) and a large amount of white columnar particles (2\#) appear in the leaching residue. Analysis of energy spectrum shows that $\mathrm{Na}, \mathrm{Al}, \mathrm{Si}, \mathrm{O}$, and a small amount of $\mathrm{K}$ exist in the melt and columnar particles. It can be inferred that the columnar particles should be albite phase. The melt should be the composite system with Na-K-Al-Si-O which converted from the dehydroxy mica. The albite will be formed from the melt during roasting process. Melting occurs in the part where the quartz coexists with the melt (Figure $4 b$ ).

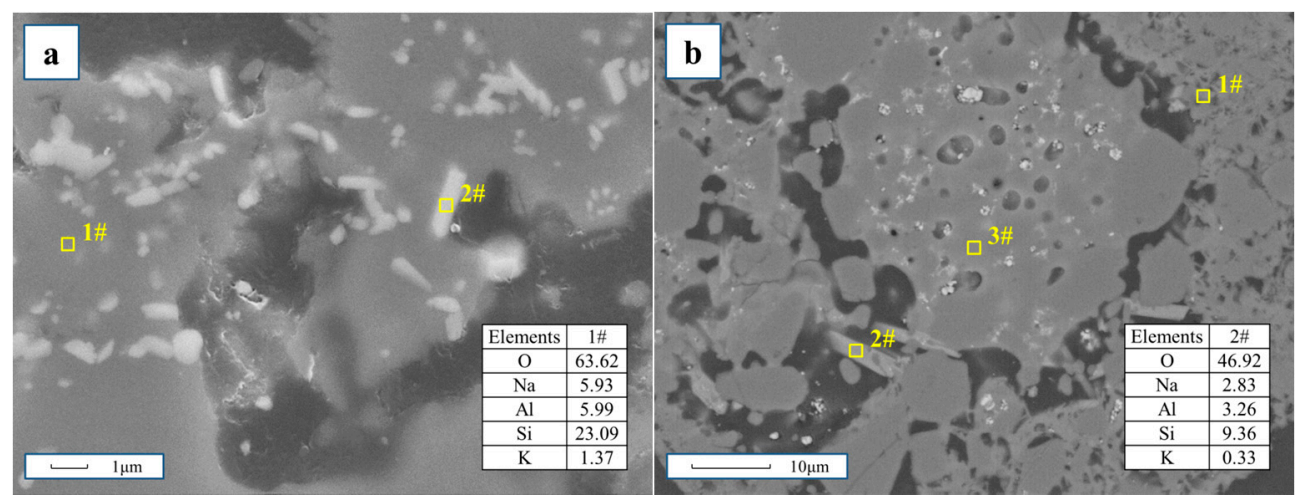

Figure 4. The SEM pattern of $\mathrm{NaCl}-\mathrm{Na}_{2} \mathrm{CO}_{3}$ composite salt leaching residue. (a) Melt and the white particles therein, (b) The melting part of ore. 1\#-melt, 2\#-albite, and 3\#-quartz. 
This indicates that $\mathrm{V}(\mathrm{III})$ is rapidly oxidized to $\mathrm{V}(\mathrm{IV})$ with the destruction of mica lattice after the removal of hydroxyl. While V(IV) exist in the newly-formed melt of K-Al-Si-O. V(IV) continues to oxidize and reacts with the additive to form the vanadate. The eutectic temperature between $\mathrm{NaCl}$ and $\mathrm{Na}_{2} \mathrm{CO}_{3}$ is $908 \mathrm{~K}$. During the roasting process $(1073 \mathrm{~K})$, the contact area between $\mathrm{NaCl}-\mathrm{Na}_{2} \mathrm{CO}_{3}$ molten salt and mineral particles increases. The migration rate of ions in molten salt also increases. This accelerates the formation of vanadate and the ion exchange between $\mathrm{Na}$ and $\mathrm{K}$. As the potassium ions are substituted by sodium ions, the content of sodium in the melt increases, and the albite gradually crystallizes from melt. The existence of $\mathrm{Na}_{2} \mathrm{CO}_{3}$ enhances the reactivity of quartz. The albite crystallized from the melt reacts with quartz and melts again, which accelerate the process of the substitution of sodium ions and the generation of vanadate. The synergistic effect between $\mathrm{NaCl}$ and $\mathrm{Na}_{2} \mathrm{CO}_{3}$ leads to the actual content of $\mathrm{V}(\mathrm{V})$ above the weighted value.

Figure 5 is a leaching residue after adding the composite additive of $\mathrm{NaCl}-\mathrm{Na}_{2} \mathrm{SO}_{4}$. Melt (1\#) and two different sizes of white columnar particles (2\# and 3\#) appear in the leaching residue. Analysis of the energy spectrum shows that the melt is a composite system with $\mathrm{Na}, \mathrm{K}, \mathrm{Al}, \mathrm{Si}, \mathrm{O}$, and a small amounts of V. The large columnar particles (2\#), about $2 \mu \mathrm{m}$ in length and width of $1 \mu \mathrm{m}$, contains mainly $\mathrm{Fe}, \mathrm{Al}, \mathrm{Cr}$, and $\mathrm{O}$. The small columnar particles (3\#), about $1 \mu \mathrm{m}$ in length and width of only $0.1-0.2 \mu \mathrm{m}$, contains mainly $\mathrm{Na}, \mathrm{Al}, \mathrm{Si}, \mathrm{O}$, and a small amount of $\mathrm{K}$. According to the magnesium-aluminum-chromium phase diagram, the small columnar particles are albite and the large columnar particles should be a kind of spinel which contains Fe and Cr.

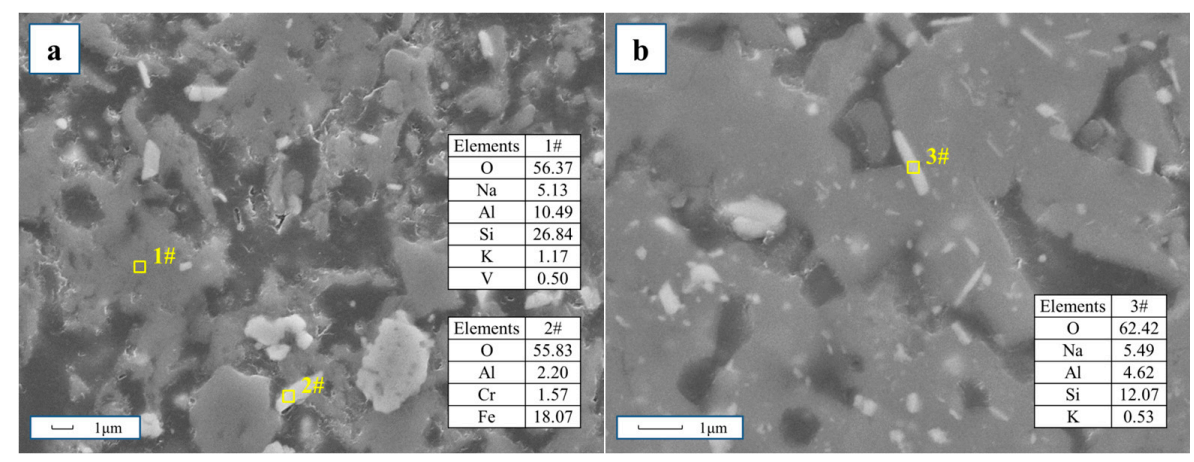

Figure 5. The SEM pattern of $\mathrm{NaCl}-\mathrm{Na}_{2} \mathrm{SO}_{4}$ composite salt leaching residue. (a) The large white particles in the melt, (b) The small white particles in the melt. 1\#-melt, 2\#-spinel, and 3-albite.

This indicates that $\mathrm{Na}_{2} \mathrm{SO}_{4}$ promotes the production of spinel in the composite system without enhancing thereactivity of quartz. The melting of $\mathrm{NaCl}-\mathrm{Na}_{2} \mathrm{SO}_{4}$ during roasting process (the eutectic temperature between $\mathrm{NaCl}$ and $\mathrm{Na}_{2} \mathrm{SO}_{4}$ is $891 \mathrm{~K}$ ) further accelerates this process. As aluminum ions participate in the generation of spinel, the crystallization process of albite is weakened. Ion exchange between molten salt and melt are also hindered. The decrease of the crystallization process of the albite indicates that the ion exchange between the sodium salt and the melt is hindered. Parts of V(IV) still exist in the melt, this indicates that the oxidation reaction of $\mathrm{V}(\mathrm{IV})$ and the generation reaction of vanadate are incomplete. $\mathrm{NaCl}$ and $\mathrm{Na}_{2} \mathrm{SO}_{4}$ have no significant synergistic effect, so that the actual content of $\mathrm{V}(\mathrm{V})$ is similar to the weighted value of $\mathrm{V}(\mathrm{V})$.

Figure 6 shows the leaching residue after adding the composite additive of $\mathrm{Na}_{2} \mathrm{SO}_{4}-\mathrm{Na}_{2} \mathrm{CO}_{3}$. Melt (1\#) and the large particles with smooth surface (2\#) appear in the leaching residue. The melt connects the large particles to each other, and the white columnar particles disappear. Analysis of the energy spectrum shows that there are $\mathrm{K}, \mathrm{Al}, \mathrm{Si}, \mathrm{O}, \mathrm{Na}$, and $\mathrm{V}$ containing in the melt. The content of $\mathrm{K}$ and $\mathrm{V}$ in the melt are higher than that in the ore, but the content of $\mathrm{Na}$ is less. The large particles, which mainly contain Si and $\mathrm{O}$, should be quartz.

The eutectic temperature $(1101 \mathrm{~K})$ between $\mathrm{Na}_{2} \mathrm{CO}_{3}$ and $\mathrm{Na}_{2} \mathrm{SO}_{4}$ is higher than the roasting temperature $(1073 \mathrm{~K})$. During roasting process, the two salts are still solid, which makes the contact 
area between the melt surface and them smaller. The ion exchange process between the melt and the sodium salt is not obvious, and there are still a large number of $\mathrm{K}$ and V exist in the melt. Melting of ore also makes the permeability of the ore worse, $\mathrm{V}(\mathrm{IV})$ is difficult to oxidation. A reverse synergistic effect occurs between $\mathrm{Na}_{2} \mathrm{CO}_{3}$ and $\mathrm{Na}_{2} \mathrm{SO}_{4}$, and the actual content of $\mathrm{V}(\mathrm{V})$ is lower than the weighted value.

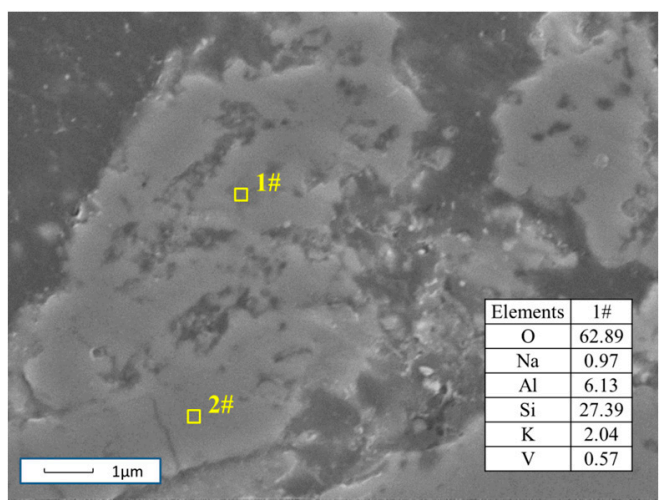

Figure 6. The SEM pattern of $\mathrm{Na}_{2} \mathrm{SO}_{4}-\mathrm{Na}_{2} \mathrm{CO}_{3}$ composite salt leaching residue. 1\#-melt, and 2 -quartz.

Figure 7 shows the XRD patterns of the three leaching residues mentioned above. The analysis of the spectrum (1) shows that albite, anorthoclase, anorthite, and pyroxene (containing $\mathrm{Mg}$ and $\mathrm{Fe}$ ) are generated in roasted slag. This indicates that composite salts of $\mathrm{NaCl}-\mathrm{Na}_{2} \mathrm{CO}_{3}$ promote the ion exchange between sodium salts and the melt and promote the generation of aluminosilicate minerals containg $\mathrm{Ca}, \mathrm{Mg}$, or Fe. The analysis of the spectrum (2) shows that albite disappears in roasted slag, and chromohercynite containing $\mathrm{Fe}$ and $\mathrm{Cr}$ generated. The peaks of anorthoclase and andesine are weaker than those in spectrum (1). This indicates that composite salts of $\mathrm{NaCl}-\mathrm{Na}_{2} \mathrm{SO}_{4}$ promote the generation of the mineral with spinel structure, and have a negative effect on the ion exchange between sodium salts and the melt. The analysis of the spectrum (3) shows that only the mineral phase of the microcline of low intensity of peak generated in roasted slag. This confirms that the sample has melted under the influence of the composite salts of $\mathrm{Na}_{2} \mathrm{SO}_{4}-\mathrm{Na}_{2} \mathrm{CO}_{3}$. The intensity of the quartz diffraction peak is weakened, which also indicates that the melting of the ore affects the crystal structure of quartz.

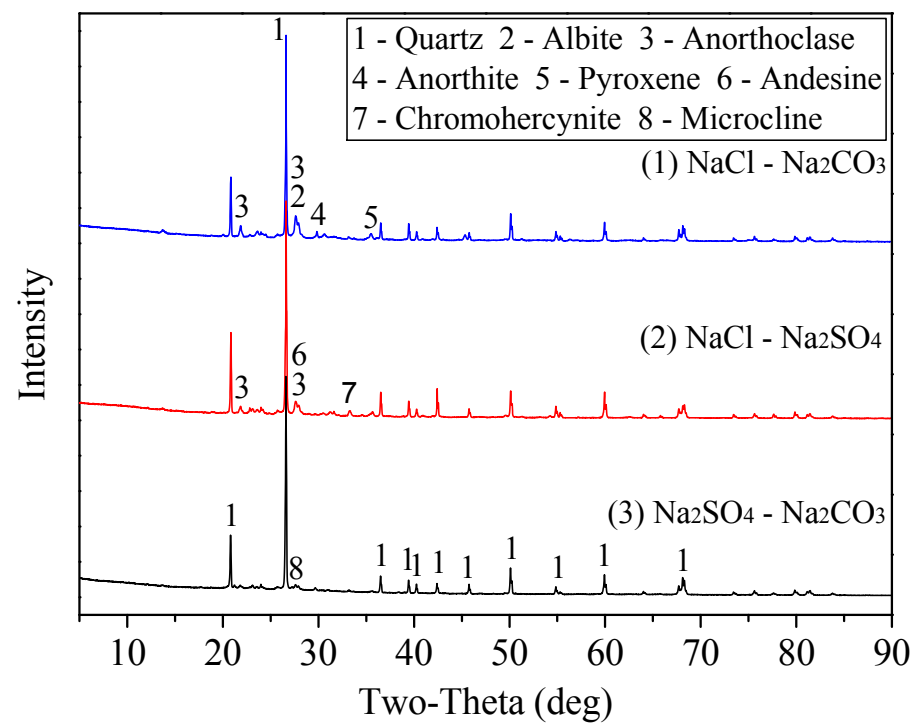

Figure 7. The XRD pattern of leaching residues added with a composite additive. 


\subsection{Influence of a Composite Additive of Three Sodium Salts on the Oxidation Process of Vanadium}

The simplex lattice mixture experiment of composite additives in roasted slag was designed. Keeping the total amount of additives unchanged, the effects of different ratio additives on the content of $\mathrm{V}(\mathrm{V})$ in roasting slag were further studied as well. Table 3 shows the factors and the levels of mixture experiments.

Table 3. The factors and levels of mixture experiments.

\begin{tabular}{cccc}
\hline Factor & Name & Low Level Values (\%) & High Level Values (\%) \\
\hline $\mathrm{A}$ & $\mathrm{NaCl}$ & 0 & 10 \\
$B$ & $\mathrm{Na}_{2} \mathrm{SO}_{4}$ & 0 & 10 \\
$\mathrm{C}$ & $\mathrm{Na}_{2} \mathrm{CO}_{3}$ & 0 & 10 \\
\hline
\end{tabular}

Through the fitting of the experimental results, the order of influence of each factor on $V(V)$ content can be obtained. Models of linear, quadratic, cubic, and special cubic can be used to fit the results of $\mathrm{V}(\mathrm{V})$ in roasted slag.

For each fitting model, the probability value ("Prob $>$ F") should be examined to see if it falls below 0.05 [15]. The extremely low $p$-value indicates a highly significant advantage when adding this level to what has already been built [16]. The results indicates that the fitting model of quadratic is relatively suggested. The $p$ values were all smaller than 0.05 , which indicates that these models reached statistical significance.

According to Table 4, the quadratic model is the best, because of its lower std. dev. (standard deviation) and better R-squared values—raw, adjusted, and predicted compared with lower-order models. Therefore, the special cubic model is suitable to fit the experimental results.

Table 5 showed the confidence degree analysis of special cubic model. The results indicated that the fitting results of special cubic model are significant. As can be seen from coefficient estimates in Table 5, the impact sequence of single factors to $\mathrm{V}(\mathrm{V})$ of roasted slag is shown as: $\mathrm{NaCl}>\mathrm{Na}_{2} \mathrm{SO}_{4}>$ $\mathrm{Na}_{2} \mathrm{CO}_{3}$. The impact sequence of multiple factors to $\mathrm{V}(\mathrm{V})$ of roasted slag is presented as: $(\mathrm{NaCl} \times$ $\left.\mathrm{Na}_{2} \mathrm{CO}_{3}\right)>\left(\mathrm{Na}_{2} \mathrm{SO}_{4} \times \mathrm{Na}_{2} \mathrm{CO}_{3}\right)>\left(\mathrm{NaCl} \times \mathrm{Na}_{2} \mathrm{SO}_{4}\right)$. This indicates that these composite of the three salts can further promote the increase of $\mathrm{V}(\mathrm{V})$. In addition, the effect of composite salt of $\mathrm{NaCl}$ and $\mathrm{Na}_{2} \mathrm{CO}_{3}$ is stronger than that of the other two kinds of composite salts.

Table 4. Variance analysis results of various models.

\begin{tabular}{ccccccc}
\hline Source & Std. Dev. & R-Squared & $\begin{array}{c}\text { Adjusted } \\
\text { R-Squared }\end{array}$ & $\begin{array}{c}\text { Predicted } \\
\text { R-Squared }\end{array}$ & PRESS \\
\hline Linear & 14.48 & 0.4340 & 0.2722 & -2.2206 & 8348.68 & Suggested \\
Quadratic & 5.35 & 0.9558 & 0.9005 & -0.9683 & 5102.40 & 8175.88 \\
Special Cubic & 6.17 & 0.9559 & 0.8677 & -2.1540 & $5.774 \times 10^{5}$ \\
Cubic & 6.92 & 0.9815 & 0.8338 & -221.7276 & \\
\hline
\end{tabular}

Table 5. The confidence degree analysis of the special cubic model.

\begin{tabular}{ccccccc}
\hline Factor & $\begin{array}{c}\text { Coefficient } \\
\text { Estimate }\end{array}$ & $\begin{array}{c}\text { df (Degree of } \\
\text { Freedom) }\end{array}$ & $\begin{array}{c}\text { Standard } \\
\text { Error }\end{array}$ & 95\% CI Low & 95\% CI High & $\begin{array}{c}\text { VIF (Variance } \\
\text { Inflation Factor) }\end{array}$ \\
\hline $\mathrm{A}-\mathrm{NaCl}$ & 59.71 & 1 & 5.31 & 44.97 & 74.44 & 1.88 \\
$\mathrm{~B}-\mathrm{Na}_{2} \mathrm{SO}_{4}$ & 43.84 & 1 & 5.31 & 29.10 & 58.57 & 1.88 \\
$\mathrm{C}-\mathrm{Na}_{2} \mathrm{CO}_{3}$ & 14.98 & 1 & 5.31 & 0.24 & 29.71 & 161.32 \\
$\mathrm{AB}$ & 40.29 & 1 & 43.59 & -80.74 & 242.74 & 5.38 \\
$\mathrm{AC}$ & 121.70 & 1 & 43.59 & 0.67 & 5.38 \\
$\mathrm{BC}$ & 82.39 & 1 & 43.59 & -38.64 & 203.43 \\
\hline
\end{tabular}


The multiple regression equation of special cubic model between $\mathrm{V}(\mathrm{V})$ and every factor could be expressed as Equation (2):

$$
\mathrm{V}(\mathrm{V}) \text { content }=5.97 \times \mathrm{A}+4.38 \times \mathrm{B}+1.50 \times \mathrm{C}+0.40 \times \mathrm{A} \times \mathrm{B}+1.22 \times \mathrm{A} \times \mathrm{C}+0.82 \times \mathrm{B} \times \mathrm{C}
$$

According to the regression equation, the contour and response surface of the relationship between $\mathrm{V}(\mathrm{V})$ and composite additives were obtained, as shown in Figures 8 and 9.

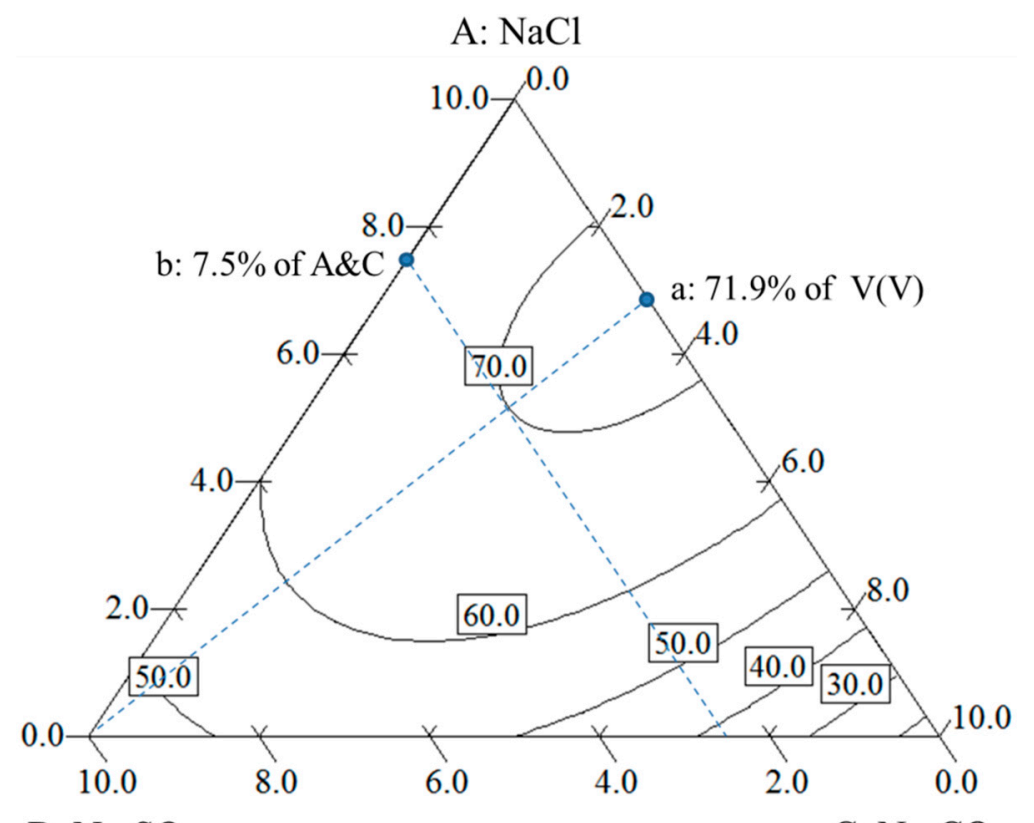
B: $\mathrm{Na}_{2} \mathrm{SO}_{4}$
$\mathrm{C}: \mathrm{Na}_{2} \mathrm{CO}_{3}$

Figure 8. Contours among $\mathrm{NaCl}, \mathrm{Na}_{2} \mathrm{SO}_{4}$, and $\mathrm{Na}_{2} \mathrm{CO}_{3}$ for $\mathrm{V}(\mathrm{V})$ of roasted slag.

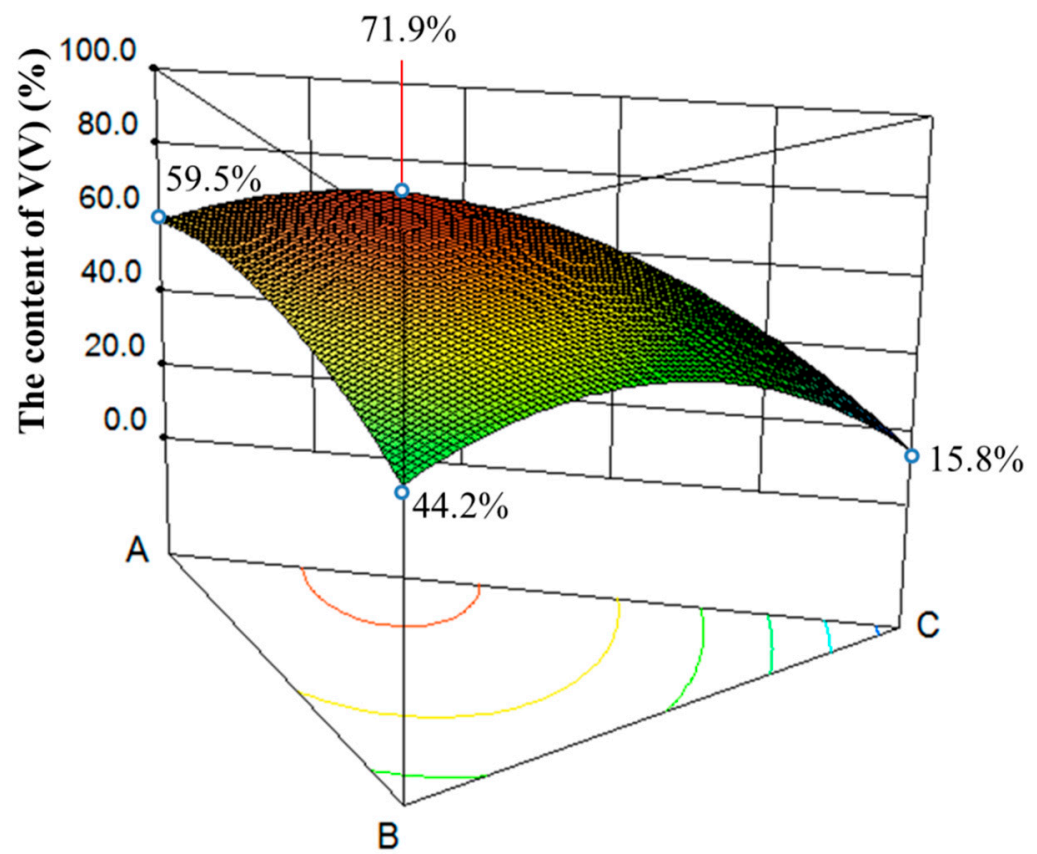

Figure 9. Response surface among $\mathrm{NaCl}, \mathrm{Na}_{2} \mathrm{SO}_{4}$, and $\mathrm{Na}_{2} \mathrm{CO}_{3}$ for $\mathrm{V}(\mathrm{V})$ of roasted slag. 
In Figure 9, the composite additive with three sodium salts shows a significant increase in $V(V)$ of the roasted slag when it is compared to the composite additive with two sodium salts. The maximum content of $\mathrm{V}(\mathrm{V})$ in roasted slag is $71.9 \%$, and the corresponding ratio of $\mathrm{NaCl}: \mathrm{Na}_{2} \mathrm{SO}_{4}: \mathrm{Na}_{2} \mathrm{CO}_{3}=$ 6.73:0.01:3.26 (Figure 8a). In Figure 8, point a is located in a region where the contour line of $70 \%$ of the $\mathrm{V}(\mathrm{V})$ content and the $\mathrm{AC}$ boundary intersect. Along the direction from the point a to points $\mathrm{A}, \mathrm{B}$, and $C, V(V)$ content gradually reduced. Along the $a B$ line, the reduction speed of the $V(V)$ content is slowest; along the $\mathrm{aC}$ line, the reduction speed of the $\mathrm{V}(\mathrm{V})$ content is fastest. It is shown that the contribution of $\mathrm{NaCl}$ and $\mathrm{Na}_{2} \mathrm{CO}_{3}$ to $\mathrm{V}(\mathrm{V})$ in the roasted slag is the highest among the three sodium salts. Under the condition that the ratio of $\mathrm{NaCl}$ and $\mathrm{Na}_{2} \mathrm{CO}_{3}$ was fixed, the low content of $\mathrm{Na}_{2} \mathrm{SO}_{4}$ (less than $25 \%$ in the composite additive, $b$ in Figure 8 ) did not significantly affect the $V(V)$ content in the roasted slag. On the contrary, the high content of $\mathrm{Na}_{2} \mathrm{SO}_{4}$ (more than $25 \%$ in the composite additive) would make the $\mathrm{V}(\mathrm{V})$ content in roasted slag decreases.

Based on the experimental results and the multiple regression equation of fitting model, the optimization for the level of every factor could be concluded on the basis of the maximum amount of $\mathrm{V}(\mathrm{V})$. When the mass fraction of $\mathrm{NaCl}$ about composite additive was $6.73 \%$, the mass fraction of $\mathrm{Na}_{2} \mathrm{SO}_{4} 0.01 \%$, and that of $\mathrm{Na}_{2} \mathrm{CO}_{3} 3.26 \%$, the maximum amount of $\mathrm{V}(\mathrm{V})$ of $71.90 \%$ could be obtained.

\subsection{Reaction Process Between Composite Additive and Siliceous Shale during the Roasting Process}

According to the above, the synergistic effect of sodium salts is mainly due to the effect of sodium salts on the change of mineral phase. With the change of mineral phase, the vanadium existence state changes, and the content of $\mathrm{V}(\mathrm{V})$ increases. Figure 10 is the model of reaction process between composite additive and siliceous shale.

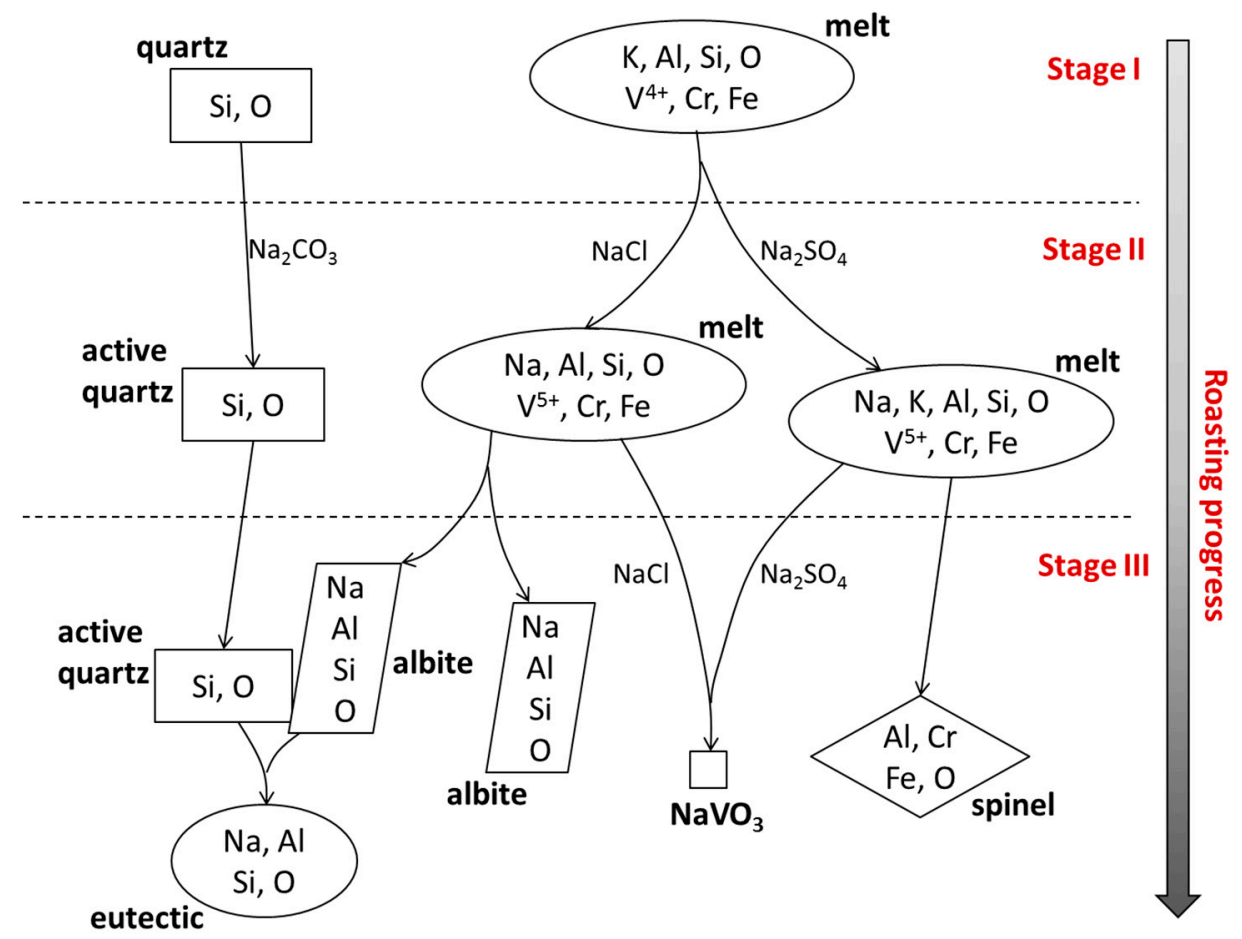

Figure 10. The model of reaction process between composite additive and siliceous shale.

Figure 10 shows that the mineral phase gradually changes under the effect of the composite additive as the roasting time increases. In the initial stage of roasting, the mica with a damaged layer structure forms an amorphous melt which mainly contains elements such as $\mathrm{K}, \mathrm{Al}$, $\mathrm{Si}$, and $\mathrm{O}$. At this time V(III) is oxidized to be V(IV). Subsequently, the three sodium salts begin to react with the ore. The generation of melt increases the contact area between the two phases and accelerates the progress 
of the reaction process. $\mathrm{NaCl}$ is the most likely to exchange ions with the melt among the three salts. $\mathrm{V}(\mathrm{IV})$ in the melt is oxidized to $\mathrm{V}(\mathrm{V})$ and reacts with $\mathrm{NaCl}$ to form the sodium vanadate. At the same time, the exchange of $\mathrm{Na}$ ions with $\mathrm{K}$ ions increases the content of $\mathrm{Na}$ in the melt and promotes the crystallization of the columnar albite from the melt. The binding capacity of $\mathrm{Na}_{2} \mathrm{SO}_{4}$ with vanadium is weaker than that of $\mathrm{NaCl}$. Thus, some vanadium in the melt cannot be further oxidized and participate in the formation of vanadate. The ion exchange capacity of $\mathrm{Na}_{2} \mathrm{SO}_{4}$ with melt is also weaker than that of $\mathrm{NaCl}$. Parts of the melt which contact with $\mathrm{Na}_{2} \mathrm{SO}_{4}$ have less content of $\mathrm{Na}$. Thus, $\mathrm{Cr}, \mathrm{Fe}$, and other elements in these parts are combined with Al-O bonds and crystallizes in the form of spinel. The ion exchange of $\mathrm{Na}_{2} \mathrm{CO}_{3}$ with melt is the most difficult. However, the addition of $\mathrm{Na}_{2} \mathrm{CO}_{3}$ could increase the alkalinity of the ore. At higher alkalinity, the reactivity of quartz in the ore enhances, and the albite reacts with the active quartz and the eutectic. When $\mathrm{Na}_{2} \mathrm{CO}_{3}$ content is low, the eutectic consumes the albite crystallized from the melt. In this way, the binding reaction of $\mathrm{Na}$ and $\mathrm{V}$ in the melt and the crystallization process of albite accelerate and the content of $\mathrm{V}(\mathrm{V})$ increases.

\section{Conclusions}

1. The composite additive of $\mathrm{NaCl}-\mathrm{Na}_{2} \mathrm{CO}_{3}$ promotes the oxidation process of vanadium and increases the content of $\mathrm{V}(\mathrm{V})$ in roasted slag. There is no obvious further promotion between $\mathrm{NaCl}$ and $\mathrm{Na}_{2} \mathrm{SO}_{4}$ on the oxidation of vanadium. The composite additive of $\mathrm{NaCl}-\mathrm{Na}_{2} \mathrm{CO}_{3}$ hinder the oxidation process of vanadium and reduces the content of $\mathrm{V}(\mathrm{V})$ in roasted slag.

2. Dehydroxy mica will convert to the melt, which mainly contains $\mathrm{Na}, \mathrm{K}, \mathrm{Al}$, Si, and $\mathrm{O}$ during the roasting process. Under the action of $\mathrm{NaCl}-\mathrm{Na}_{2} \mathrm{CO}_{3}$, the process of sodium ions replace potassium ions in the melt, promoting the crystallization of albite. The existence of $\mathrm{Na}_{2} \mathrm{CO}_{3}$ enhances the reactivity of quartz. The albite reacts with the activated quartz and melts. These reactions accelerate the generation of vanadate.

3. Under the action of $\mathrm{NaCl}-\mathrm{Na}_{2} \mathrm{SO}_{4}$, The crystallization process of spinel in the melt is promoted and the crystallization process of the albite is inhibited. There is no significant synergistic effect of $\mathrm{NaCl}$ and $\mathrm{Na}_{2} \mathrm{SO}_{4}$ on vanadium oxidation. Under the action of $\mathrm{Na}_{2} \mathrm{SO}_{4}-\mathrm{Na}_{2} \mathrm{CO}_{3}$, the ion exchange process and the vanadium oxidation are inhibited in the melt. A reverse synergistic effect occurs between $\mathrm{Na}_{2} \mathrm{CO}_{3}$ and $\mathrm{Na}_{2} \mathrm{SO}_{4}$.

4. The composite additive of three sodium salts contribute more to the increase of $V(V)$ than the additive of two sodium salts. Among the three sodium salts, $\mathrm{NaCl}$ and $\mathrm{Na}_{2} \mathrm{CO}_{3}$ have the most effective on the promotion of the oxidation of vanadium. Under the condition that the ratio of $\mathrm{NaCl}$ and $\mathrm{Na}_{2} \mathrm{CO}_{3}$ is fixed, and the low content of $\mathrm{Na}_{2} \mathrm{SO}_{4}$ does not significantly affect the $\mathrm{V}(\mathrm{V})$ content in the roasted slag.

Acknowledgments: This work was financially supported by the Major Science and Technology Program for Water Pollution Control and Treatment (no. 2015ZX07205-003) and the China Ocean Mineral Resources Research and Development Program (no. DY125-15-T-08).

Author Contributions: Xinlong Yang and Yali Feng conceived and designed the experiments; Xinlong Yang performed the experiments; Xinlong Yang and Haoran Li analyzed the data; Zhuwei Du contributed materials; Yali Feng and Xinlong Yang wrote the paper.

Conflicts of Interest: The authors declare no conflict of interest.

\section{References}

1. Ning, P.G.; Lin, X.; Wang, X.Y.; Cao, H.B. High-efficient extraction of vanadium and its application in the utilization of the chromium-bearing vanadium slag. Chem. Eng. J. 2016, 301, 132-138. [CrossRef]

2. He, D.S.; Feng, Q.M.; Zhang, G.F.; Ou, L.M.; Lu, Y.P. An environmentally-friendly technology of vanadium extraction from stone coal. Miner. Eng. 2007, 20, 1184-1186. [CrossRef]

3. Zhang, Y.M.; Bao, S.X.; Liu, T.; Chen, T.J.; Huang, J. The technology of extracting vanadium from stone coal in China: History, current status and future prospects. Hydrometallurgy 2011, 109, 116-124. [CrossRef] 
4. Zeng, X.; Wang, F.; Zhang, H.F.; Cui, L.J.; Yu, J.; Xu, G.W. Extraction of vanadium from stone coal by roasting in a fluidized bed reactor. Fuel 2015, 142, 180-188. [CrossRef]

5. Zhao, Y.L.; Zhang, Y.M.; Bao, S.X.; Chen, T.J.; Han, J. Calculation of mineral phase and liquid phase formation temperature during roasting of vanadium-bearing stone coal using FactSage software. Int. J. Miner. Process. 2013, 124, 150-153. [CrossRef]

6. Zhao, Y.L.; Zhang, Y.M.; Song, S.X.; Chen, T.J.; Bao, S.X. Behaviors of impurity elements Ca and Fe in vanadium-bearing stone coal during roasting and its control measure. Int. J. Miner. Process. 2016, 148, 100-104. [CrossRef]

7. Shlewit, H.; Alibrahim, M. Extraction of sulfur and vanadium from petroleum coke by means of salt-roasting treatment. Fuel 2006, 85, 878-880. [CrossRef]

8. Li, X.S.; Xie, B.; Wang, G.E.; Li, X.J. Oxidation process of low-grade vanadium slag in presence of $\mathrm{Na}_{2} \mathrm{CO}_{3}$. Trans. Nonferrous Metals Soc. China 2011, 21, 1860-1867. [CrossRef]

9. Sadykhov, G.B. Oxidation of titanium-vanadium slags with the participation of $\mathrm{Na}_{2} \mathrm{O}$ and its effect on the behavior of vanadium. Russ. Metall. 2008, 6, 449-458. [CrossRef]

10. Moskalyk, R.R.; Alfantazi, A.M. Processing of vanadium: A review. Miner. Eng. 2003, 16, 793-805. [CrossRef]

11. Chen, T.J.; Zhang, Y.M.; Song, S.X. Improved extraction of vanadium from a Chinese vanadium-bearing stone coal using a modified roast-leach process. Asia Pac. J. Chem. Eng. 2010, 5, 778-784. [CrossRef]

12. Bao, S.X.; Zhang, Y.M.; Han, J.; Yang, X.; Hu, Y.J. Determination of vanadium valency in roasted stone coal by separate dissolve-potentiometric titration method. MRS Proc. 2012, 1380, imrc2011-1380.

13. Zhang, Y.M.; Hu, Y.J.; Bao, S.X. Vanadium emission during roasting of vanadium-bearing stone coal in chlorine. Miner. Eng. 2012, 30, 95-98. [CrossRef]

14. Xiao, W.D. Mineralogy of stone coal from Shanglin of Guangxi and vanadium extraction with hydrometallurgical process. Nonferrous Metals 2007, 59, 85-90.

15. Mirazimi, S.M.J.; Abbasalipour, Z.; Rashchi, F. Vanadium removal from LD converter slag using bacteria and fungi. J. Environ. Manag. 2015, 153, 144-151. [CrossRef]

16. Nazari, E.; Rashchi, F.; Saba, M.; Mirazimi, S.M.J. Simultaneous recovery of vanadium and nickel from power plant fly-ash: Optimization of parameters using response surface methodology. Waste Manag. 2014, 34, 2687-2696. [CrossRef] 